catalytic mechanisms involved. The flood of articles relating to possible mechanisms and other theoretical aspects has been immense. The volume of this-often controversial-literature and the extensive data contained in hundreds of patents make a survey of the field very difficult. In spite of these problems the increase in knowledge in this comparatively new major area of research is enormous. In this sense the present threevolume work, in which an attempt has been made to bring together the latest knowledge of stereospecific poly merization, is very welcome and of considerable value.

Volume 1 presents a compilation of the latest points of view of Ziegler--Natta catalysts of the polymerization of olefines and dienes. In volume 2 the emphasis is shifted to stereospecific polymerization by catalysts other than the Ziegler-Natta type. [Volume 3-to be published shortly-deals with the determination of the steric structure of polymers and the influence of structural features on physical, mechanical and chemical properties of polymers.]

In the two volumes being reviewed the emphasis is placed on the mechanism of the reaction. The first three chapters of volume 1 . deal with the nature and properties of the catalysts and the mechanism of olefine polymerization. The ideas of Cossee and Arlman are given a special place in that they present a definitive mechanism which may be a fruitful base for the planning of future research. The other chapters in this volume describe the copolymerizations of olefines and the polymerization of dienes by Ziegler-Natta catalysts. The final chapter summarizes the manufacture and commercial applications of stereoregular polymers, with particular emphasis on polypropylene.

The various chapters of volume 2 cover the stereospecific polymerization of: (1) vinyl type monomers by alkali-metal based catalysts; (2) vinyl ethers; (3) aldehydes, ketones and ketenes; (4) epoxides; and (5) free radicals. Chapter 6 deals with conformational effects induced in polymers by rigid matrices such as solid state and surface polymerization, canal complexes, etc. The final chapter, which summarizes briefly those stereo. regular polymers which function as structural materials or as reserve food materials in the living cell, namely, starch, glycogen, cellulose, glucose and other sugars, and rubber, directs the attention of the reader to the huge and largely unexplored but extremely important study of biological macromolecular systems.

The volumes provide a very fascinating and excellent survey of a very significant area of polymer science and can be recommended to all scientists and technologists interested in the stereochemistry of macromolecules.

$$
\text { C. E. H. BAwN }
$$

\section{QUESTION AND ANSWER}

\section{Dialogues on Fundamental Questions of Science and Philosophy}

By A. Pfeiffer. Translated from the German by Jutta Mendelssohn and Ursula Meadows. (The Commonwealth and International Library of Science, Technology, Engineering and Liberal Studies.) Pp. xi +128 . (Oxford, London and New York: Pergamon Press, 1967.) 25s. net. THrs little book consists of a series of dialogues, largely on the seventeenth-eighteenth century pattern, dealing with the fundamental issues in seience and philosophy. There is also a very telling foreword by $\mathrm{Dr} \mathrm{K}$. Mendelssohn. The first part is concerned with science and theory of cognition, whereas the second deals with the ethical problem, nature and culture. In a word, these pages record the experience of one born into a world of order and stability, who lives to see most of that milieu broken and shattered into a soulless materialism, which his logic and surroundings compel him to accept. Professor
Pfeiffer says that his teachers were Planck and Nernst (and who could possibly have had better?), yet his reactions are very different. He became chief scientist to a large scientific instrument company-one can guess that it was Zeiss or Leitz-and then was absorbed behind the iron curtain. Question and answer are obviously those of the author before and after the main transitions. in his life. He comes to the conclusion-not a very novel one-that science and art can be accepted by intelligent mankind as substitutes for religion. Yet he cannot wholly obliterate his early impressions, which leave a hankering for metaphysics and a strong tension between biology and ethics; indeed, every indication of a mind in torment.

These "conversations" are worth careful reading; they are good-tempered and well to the point. What they lack, perhaps only to people whose lives are quite different, is any basic sense of humility. There is no place for the numinous, no recognition of the "wholly other", as another, and possibly greater, German philosopher has written.

Professor Pfeiffer, now at Dresden, has given the West something to think about. The city of his adoption was at one time indeed the Temple of the Muses. One wonders whether it will become so again, and so hospitable, if his philosophy takes its icy grip on mankind.

\section{F. I. G. RAWLINS}

\section{PLANCK'S LIFE AND WORK}

\section{Max Planck als Philosoph}

By Hermann Kretzschmar. Pp. 116. (München und Basel : Ernst Reinhardt, 1967.) 11 DM.

From time to time articles have appeared in various places dealing with the life and work of the great theoretical physicist, Max Planck. Good as some of them are, they tend to get lost or to become inaccessible as time goes on. Now we have a very readable and handy biography. Of all men, Planck needs a sympathetic recorder who understands genius and can make it live. The title is significant, "Planck as Philosopher". Roughly, a couple of world generations sometimes have little idea beyond $h=6.55 \times 10^{-27}$ ergs what it is all about. This book goes far to lift the veil.

We are now a hundred and ten years away from Planck's birth, not a great span in historical time, but a vast distance in terms of philosophical physics. Moreover, the effect on collateral subjects has been profound. For example, it would not be far wrong to claim the master of the quantum theory as the greatest physical chemist of his generation; yes, greater than Nernst and more powerful than Ostwald or Clausius, both of whom did much for what is now taken to be chemical physics.

To accept all this is to realize what the present author is striving to proclaim. The essence of Planck's stature was his reluctance. Born into a distinguished legal family, graduating "summa cum lande", but without too much praise, he subsequently revealed a veneration for natural law no less profound than that of Leonardo da Vinci. And yet how differently it functioned. Planck cared little for applied science and mechanical contrivances. He was convinced that one law governed nature and mankind's grasp of it. Law was absolute, not statistical. Hence his struggle against discontinuity and Boltzmann's position. Time and again he veered away from the great edifice of physics which his logic forced him to recognize. Here was manifested his inveterate reluctance.

In one important respect Planck acted true to type, in that with advancing years he became more and more interested in philosophical questions, one aspect of his talents with which these pages are most concerned. There was a parallelism between thought and nature. He was 